\title{
O Teatro de Marcelo: historiografia e percepção do espaço teatral (séc. I a.C.)
}

\author{
Letícia Aga Pereira Passos*
}

\begin{abstract}
PASSOS, L.A.P. O Teatro de Marcelo: historiografia e percepção do espaço teatral
\end{abstract} (séc. I a.C.). R. Museu Arq. Etn., 36 191-211, 2021.

Resumo: No período de transição entre a República e o Principado, juntamente com as artes, a literatura e a arquitetura, a imagem urbana de Roma foi usada pelo Imperador Augusto como uma ferramenta para legitimar o poder de seu novo governo e sua própria imagem. Como herdeiro de Júlio César, o princeps objetivou modernizar a cidade construindo grandiosos monumentos públicos. Dentre as construções, situa-se o Teatro de Marcelo, um dos maiores teatros do Império Romano. Utilizado pela primeira vez em 17 a.C. para os Jogos Seculares e dedicado formalmente ao sobrinho e herdeiro do Imperador Augusto, o teatro era capaz de receber mais de 15 mil pessoas. Apesar das mudanças inerentes à passagem do tempo e às restaurações realizadas, a estrutura monumental do teatro permanece até os dias atuais. Assim, aprofundando o estudo a respeito do espaço físico teatral, buscaremos expor sobre a construção do Teatro de Marcelo, indicando sua estrutura interna e suas inovações arquitetônicas. Por se tratar de um monumento que encontra um certo abandono na historiografia atual, objetivamos discutir a bibliografia acerca do Teatro de Marcelo, que nos fornece a complexidade de suas plantas baixas e suas descobertas arqueológicas. Por fim, iremos apresentar duas reconstituições tridimensionais encontradas, debatendo sobre o espaço em três dimensões com as informações historiográficas.

Palavras-chave: Principado; Augusto; Teatro de Marcelo; Espaço teatral; Reconstituição tridimensional.

\section{Introdução}

entretenimento teatral possui uma
longa história na Roma Antiga. Parte importante da literatura latina é composta por roteiros de peças de teatros, traduzidas primeiramente do modelo grego para uma audiência romana por homens como Lívio Andrônico, Gneu Névio e Plauto. Apesar da nebulosidade que envolve as várias origens do teatro romano, os primeiros jogos cênicos

* Mestra em História e Cultura Política pelo Programa de Pós-Graduação da Universidade Estadual Paulista (Unesp Campus de Franca/SP).<leticiaagapereirapassos@gmail.com> (ludi scaenici) aconteceram em 364 a.C., quando um grupo teatral etrusco composto por bailarinos, músicos e mimos foi chamado pelo Senado para que esconjurasse uma epidemia de peste (Grimal 1978: 79-80). Profundamente ligada aos deuses, a arte do teatro foi organizada pelos romanos com base no programa de suas festividades, tais como os Ludi Cereales e Megalenses, em homenagem à mãe dos deuses, e os Ludi Apollinares, em honra ao deus Apolo (Berthold 2001: 141).

Esses espetáculos aconteciam em vários lugares da cidade de Roma, dependendo da região. Políbio descreve um espetáculo cênico organizado pelo propraetor Lúcio Anício no Circo Máximo em 
167 a.C.: "Tendo convocado os artistas mais ilustres da Grécia e construído um palco muito grande no Circo, ele trouxe flautistas pela primeira vez... postando-os em frente do palco, ele os dirigiu para tocarem junto" (Polybius 2012: 30; Athenaeus 1854: 14.6). Outros relatos sobre espetáculos destacam também suas realizações no Circo Flamínio e em frente a templos, como os Ludi Megalenses realizados na frente do Templo de Cibele ou Magna Mater (Sear 2006: 54).

Assim, as origens do teatro romano dividem-se, inicialmente, entre o florescimento das atividades dramático-literárias, entre os séculos III e II a.C., e um posterior esforço de criação de uma moldura arquitetônica, entre os séculos I e II d.C. (Berthold 2001: 140). Até o final da República, o teatro romano estava limitado a estruturas de madeiras provisórias, que o Senado ordenava demolir, receoso de que os romanos aderissem ao costume grego de permanecer longos períodos no teatro, tornando-se excessivamente afeitos à "moda grega" tida como prejudicial a homens de índole viril (Grimal 1978: 16; Brothers 1989: 99).

A primeira construção de um teatro de pedra foi realizada por Pompeu em 55 a.C., na cidade de Roma. Aliado e posteriormente adversário de Júlio César, Pompeu construiu um teatro inspirado nos exemplos gregos já existentes na cidade de Lesbos. Utilizando-se de um inteligente estratagema, afastou o perigo da demolição ao erguer um templo à deusa Venus Victrix, a deusa da vitória, em suas últimas fileiras. Júlio César, temendo ser ofuscado por Pompeu e perder prestígio político aos olhos do povo, também teve a intenção de construir uma obra no mesmo estilo (Grimal 2009: 243).

O Teatro de Marcelo (FIGURA 1) ainda permanece visível, e muito bem situado: foi construído na parte sul do Campo de Marte, localizado próximo ao rio Tibre e outros monumentos importantes. A obra foi concebida por Júlio César, que escolheu o lugar adequado em 46 a.C. para plantear uma área destinada a um grande público. Para colocar em prática tal intento, ordenou a remoção do templo de Pietas no fórum Holitorium, de outros santuários e de algumas casas particulares. Nas palavras de Dião Cássio, "desejando construir um teatro como Pompeu tinha feito, ele colocou as fundações, mas não terminou. O trabalho cessou após a sua morte, e só foi retomado quando Augusto assumiu o projeto novamente em 23 a.C." (Dio Cassius 1924: 53.2.).

Atribui-se a César o empenho pela construção das fundações do teatro, mas foi Augusto (Augustus Caesar 1967: 21) quem observou que a área obtida por César era insuficiente. Tal observação obrigou Augusto a custear a compra de terras privadas. Dito de outro modo, Augusto foi certamente o principal responsável pela construção do edifício (Richardson 1992: 382). Importante evidenciar que, neste momento de transição entre a República e o Principado, o jovem Otávio, filho adotivo de César, procurava ligar-se fortemente à imagem do pai, explorando até as últimas consequências sua herança política, além de empregar vários artifícios ideológicos para fortalecer seu novo governo.

Assim, ligando-se a um projeto de Júlio César, a área foi totalmente replanejada pelo novo imperador e é bem possível que o teatro possa ter sido maior do que Júlio César imaginou.

A cavea ${ }^{1}$ estava virada para sul-sudoeste, em parte para alinhá-la mais de perto com o pórtico Metelli, permitindo também a instalação de um edifício tão grande em um local tão restrito. Tais limitações territoriais - como a presença de outros monumentos no espaço - restringiram o diâmetro do teatro a 129,80 metros, número inferior ao do Teatro de Pompeu. No entanto, existem indicações de que o Teatro de Marcelo teve maior capacidade de assentos, pelo menos é o que afirmam os catálogos regionais do século IV d.C. (Valentini \& Zucchetti 1940: 123). Esses textos destacam a existência de 20.500 pés de espaço para os assentos no Teatro de Marcelo e 15.580 pés para o mesmo espaço no Teatro de Pompeu. Levando em consideração que a medida de um pé romano equivale a 0,294-0,297 metros, chegamos a um total de 15.100 lugares, com assentos de cerca de 40 centímetros de largura, no Teatro de Marcelo. A capacidade do Teatro de Pompeu foi de apenas 11.600 lugares (Sear 2006: 62).

1 A parte estrutural do teatro era denominada cavea e seria como arquibancadas, que eram divididas em ima cavea (linhas inferiores), cavea media (a parte do meio) e summa cavea (arquibancadas superiores) (Hines 2003). 


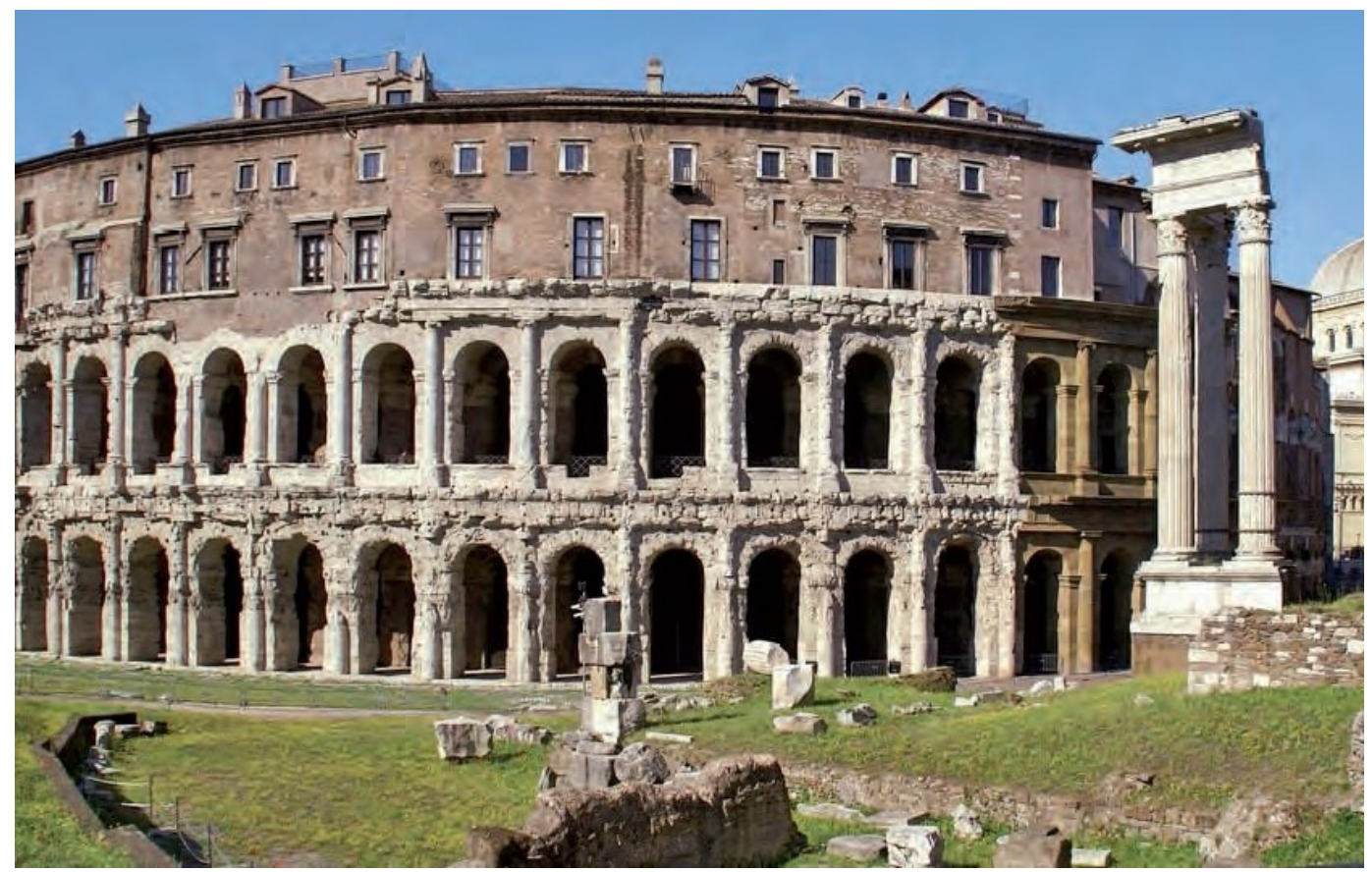

Fig. 1. Estrutura atual do Teatro de Marcelo.

Fonte: Buonfiglio (2010: 110).

O Teatro de Marcelo foi palco dos Jogos Seculares em 17 a.C., antes mesmo da conclusão do edifício. A própria realização dos jogos, organizada a cada 110 anos, servia de cenário para a apresentação das boas qualidades e da imagem idealizada do soberano. Nesses momentos festivos, o imperador era modelo de generosidade, ao promover distribuições de dinheiro ou alimentos; de força, ao ser aclamado pelas legiões e pela plebe urbana de Roma; do pontificado, ao realizar importantes ritos religiosos (jogos, peças teatrais, danças), responsáveis por garantir a proteção das divindades à prosperidade do Império. Tais jogos poderiam ser utilizados como instrumentos de poder, já que no desenrolar das festas divulgavam-se mensagens, imagens, símbolos e mitos, um meio de controle social, além de construir espaços de memória compartilhada (Gonçalves 2002: 16-17).

Naquela época, o teatro era chamado de "theatrum quod est no Circo Flaminio", até que Augusto dedicou a edificação à memória de seu sobrinho e, por certo período herdeiro do Princeps, Marco Cláudio Marcelo (falecido no ano de 23 a.C.). Em oferecimento a Marcelo, Augusto determinou que fossem feitos os jogos esplêndidos, incluindo o Lusus Troiae e uma venatio no circo (Dio Cassius 1924: 54.26; Suetonius 1914: 43). Quatro colunas de mármore de tamanho notável, usadas por Emílio Escauro na decoração do teatro provisório que ele havia construído como edil e que, em seguida, foram usadas para adornar o átrio de sua casa no Palatino, foram provavelmente utilizadas por Augustos na porta regia ${ }^{2}$ do novo teatro e na entrada central da scaenae $^{3}$ (Richardson 1992: 382).

Após Augusto, o Teatro de Marcelo foi foco de incêndios e passou por restaurações por Tito Flávio Vespasiano e Alexandre Severo. O teatro continuou em uso, uma vez que o praefectus urbi Petronius Massimo erigiu estátuas no edifício em

2 Portas presentes na scaenae frons: valva regia (porta central) porta hospitales (portas laterais à porta central) (Hines 2003).

3 Cena do teatro, atrás do palco. Era uma parede arquitetônica que se erguia à altura da cavea que reproduzia normalmente a fachada de um palácio (Silva 2015: 255). 
O Teatro de Marcelo: historiografia e percepção do espaço teatral (séc. I a.C.)

R. Museu Arq. Etn., 36: 191-211, 2021.

421 d.C. Durante o século XII foi transformado em uma fortaleza e, no início do XVI, tornou-se posse de uma importante família, que mandou construir um palazzo sobre as ruínas das fundações (Richardson 1992: 382). Entre $1926 \mathrm{e}$ 1932, o governo italiano se comprometeu a isolar a área e restaurar o interior do edifício. Porém, a exploração foi limitada devido às constantes inundações do rio Tibre e aos variados fragmentos substanciais da cavea, que demandam um cuidado especial.

Desta forma, trataremos do aspecto físico do Teatro de Marcelo, indicando sua estrutura interna e suas inovações arquitetônicas. Buscamos visualizar o teatro através de várias óticas, seja por uma breve discussão historiográfica da arqueologia sobre as plantas baixas do edifício de Marcelo e seu processo construtivo, seja pelos aspectos arqueológicos em si, como uma maior percepção de seu espaço teatral pela demonstração das reconstituições tridimensionais.

\section{Reconstituições Tridimensionais}

Uma das reconstituições em 3D abordadas pertence à professora Flavia Calisti ${ }^{4}$ e ao gráfico Dario Scoccimarro (FIGURA 2). A professora Calisti é atualmente docente de arqueologia na Universidade Popular de Roma (Upter).

4 Infelizmente não obtivemos contato com a professora para mais informações acerca do processo de construção desta restituição, ou seja, em que fontes ou desenhos ela foi baseada.
Tal projeção faz parte de um projeto intitulado Progetto Traiano, organizado por arqueólogos e engenheiros, e que objetiva "usar a moderna tecnologia de design tridimensional para materializar descobertas e observações em relação à engenharia e ao estudo arqueológico dos monumentos da Roma Antiga"5.

A segunda reconstituição encontrada foi preparada por Matthew Nicholls (FIGURA 3 e FIGURA 4), professor de História Antiga da Universidade de Reading (Reino Unido). Interessado na história política e social dos romanos, no modo como os ambientes estavam construídos e na formação da cidade de Roma ao longo do Império, o projeto intitulado Virtual Rome é uma reconstituição arquitetônica digital, isto é, cria uma visualização do conjunto urbano antigo.

5 Progetto Traiano: Teatro di Marcello. Disponível em: <https://bit.ly/3k10rmn>. Acesso em: 02/07/2019.

6 Utilizando as plantas baixas dos monumentos, o historiador desenha o modelo em 3D com o software SketchUp e utiliza também instrumentos mais complexos chamados de Cinema 4D e Lumion. O software também é utilizado por cineastas e arquitetos, uma vez que é possível inserir luz artificial, sombras e reflexos nas imagens no processo chamado de renderização. Por meio do aplicativo Kubity é possivel aproximar-se dos edifícios, caminhar por eles e assistir vídeos de "sobrevôo". Todas essas informações são retiradas do curso online do Prof. Matthew Nicolls, nomeado "Rome: a Virtual Tour of Ancient City". O curso está disponivel gratuitamente apenas em alguns períodos pelo site FutureLearn. Disponivel em: 〈https://bit.ly/38qdqPY〉. Acesso em 10/07/2020. Para outras informações sobre o Virtual Rome, conferir: 〈https://bit.ly/3bw6SRF>. Ácesso em 11/02/2021; $<$ https://bit.ly/3rBN44T>. Acesso em 10/03/2021.

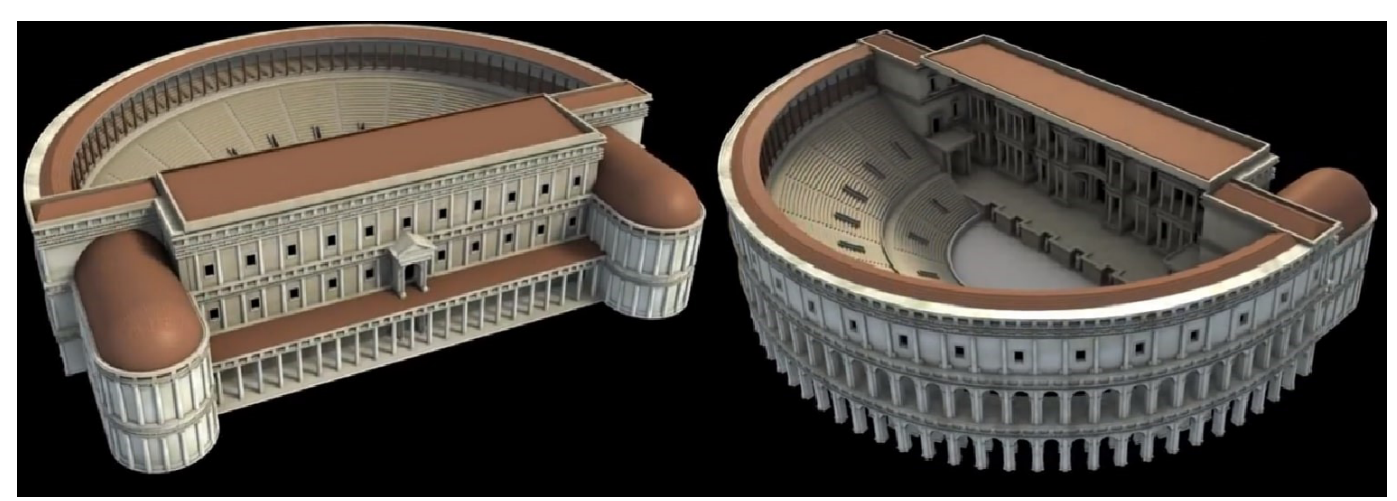

Fig. 2. Configuração tridimensional do Teatro de Marcelo, segundo Flavia Calisti.

Fonte: Progetto Traiano (2014). 
O professor Nicholls prontamente disponibilizou para esta pesquisa parte de seu projeto, a reconstituição do Teatro de Marcelo?. Umas das fontes utilizadas por Nicholls, além de seus arquivos próprios, foi a obra Rome: an Oxford archaeological guide de Amanda Claridge (2010), que utiliza desenhos de Paolo Fidenzoni ${ }^{8}$. Justificamos nossa escolha pelo

7 Para visualizar o Teatro de Marcelo pelo aplicativo Kubity, conferir: <https://bit.ly/3kZ2VYM>. Acesso em 10/07/2020.

8 Acrescentamos que esta reconstituição tridimensional tem como objetivo, segundo Nicholls, de reproduzir as elevações da cavea e criar um modelo para o palco, em vez de toda a estrutura, assim, as passagens interiores não são modeladas com precisão. projeto de Nicholls, pois visualizamos maiores semelhanças com a planta baixa do teatro em relação à divisão de assentos. No projeto de Calisti há apenas duas divisões da cavea, enquanto o projeto Virtual Rome coloca as três divisões encontradas na maioria dos teatros romanos e nas plantas baixas do Teatro de Marcelo: ima, media e summa cavea.

Outro ponto que reforça essa escolha pelo projeto em 3D com maiores divisões na plateia é devido à Lex Iulia Theatralis. Essa nova lei aprovada durante o governo de Augusto, que impunha uma ordem sob a qual os variados grupos sociais do público do teatro deveriam se sentar, tornou-se modelo para a construção de teatros em toda a Itália e no Ocidente (Claridge 2010: 275).

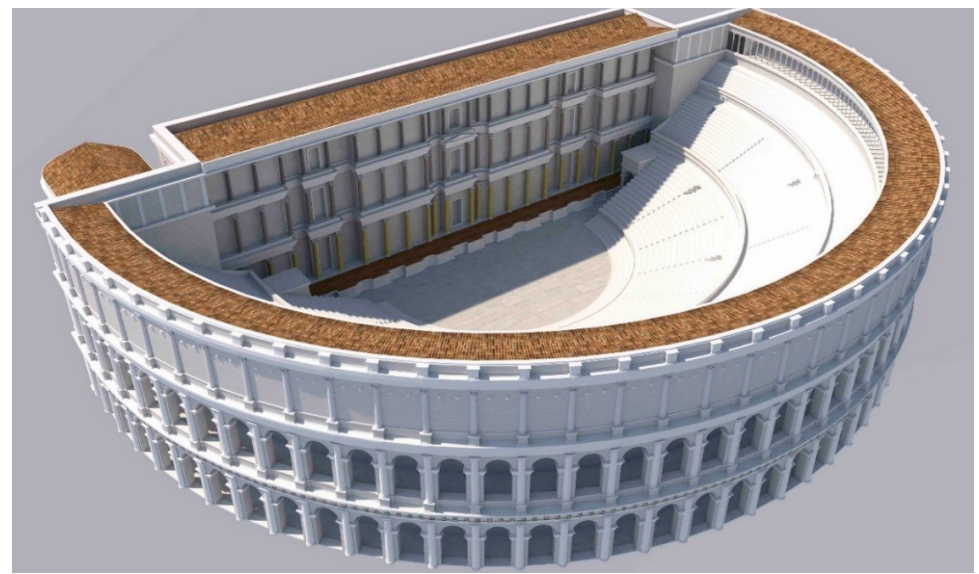

Fig. 3. Configuração tridimensional do Teatro de Marcelo, segundo Matthew Nicholls. Fonte: Kubity (2017).
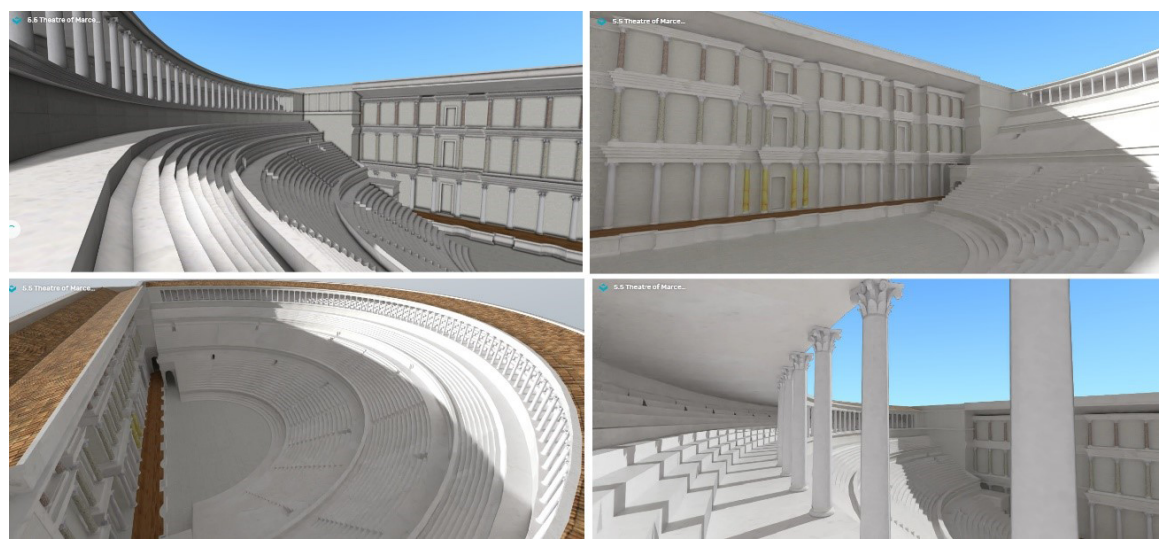

Fig. 4. Configuração tridimensional interna do Teatro de Marcelo, segundo Matthew Nicholls.

Fonte: Kubity (2017). 
Ao mesmo tempo, esse espaço integrava celebrações, atividades religiosas e de diversão, isto é, nele eram realizados diversos momentos de sociabilidade onde se reuniam vários grupos sociais romanos. Afastando-se de ideias como a romanização ou a contradição entre elementos "romanos" e "não romanos", "os pesquisadores têm hoje investido numa reflexão um pouco mais complexa, pretendendo elucidar, com base em estudos de caso, quais elementos poderiam ser interpretados como próprios de uma "cultura romana standard" (Silva 2015: 251). Ainda segundo Silva, à medida em que partimos dos estudos que englobam a identidade romana e a apropriação do espaço para compreendermos o sentimento de pertença, a adesão aos ritos e aos comportamentos comuns, bem como às suas particularidades locais,

é possivel afirmar que estes edifícios comportam uma conexão estreita entre as atividades que ai se desenvolvem e $o$ público que regularmente os ocupa, o que nos remete ao princípio da arquitetura como experiência vivida, razão pela qual a maneira como os grupos sociais se relacionam com os edifícios e monumentos, a representação que deles fazem, o significado cultural que thes são atribuidos, as regras de ocupação do recinto, nos trazem valiosas informações sobre como, no dia a dia, as hierarquias sociais são produzidas, reproduzidas e subvertidas e sobre como as identidades e alteridades são forjadas (Silva 2015: 252-253).

Como citado, o Teatro de Marcelo foi atingido por incêndios e passou por restaurações após Augusto e continuou em uso até o século $\mathrm{V}$ d.C. A parte cênica do teatro foi restaurada pelo Imperador Vespasiano. O edifício também foi usado em parte das celebrações dos Ludi Saeculares de Septímio Severo, que também planejou reparar o teatro e desviou os impostos para este fim, embora seja difícil averiguar tal questão (Sear 2006).
Na Idade Média, o edifício começou a entrar em colapso e se encheu de areia e lama em virtude das inundações do Tibre. Ocupou uma posição chave, dominando o ambiente e sendo parte da importante travessia do rio. $O$ espaço parece ter sido propriedade em primeiro lugar da família Pierleoni, no século XI, e, no final do século XIII, da família Savelli. Nesse período, o teatro começou a ser denominado quliseo de'Savelli - sua estrutura foi confundida com a de um coliseu (Fidenzoni 1970: 75).

No início do século XVI, a família Savelli decidiu reutilizar o espaço e mandou construir um palazzo sobre as ruínas das fundações, sendo o arquiteto Baldassarre Peruzzi responsável pelas mudanças. Exceto pelas transformações inerentes à passagem do tempo e às restaurações realizadas com a compra do palácio pelo Príncipe Don Domenico Orsini (em 1712), a fisionomia feita por Peruzzi caracterizou o teatro no século XVIII (Sánchez 2008: 191).

O piso principal, ou seja, o piano nobile do palácio foi construído imediatamente acima da ordem jônica. Gravuras do período mostram que a ordem dórica da fachada havia se tornado semienterrada e havia lojas nos arcos das abóbadas (fórnice). Os fórnices da ordem jônica foram emparedados e dois níveis de janelas podem ser vistos, presumivelmente representando os dois andares nos quais ele foi dividido. O palácio permaneceu nas mãos dos Savelli até que essa linhagem fosse extinta, em 1712, com a morte do Príncipe Julio Savelli, momento a partir do qual o palácio foi adquirido pela família Orsini (Sear 2006: 62).

\section{Plantas baixas do Teatro de Marcelo}

A longa trajetória dos estudos de arquitetura e a intensa atenção direcionada à topografia da Roma antiga forneceram um conjunto de imagens relacionadas à visão aérea do Teatro de Marcelo (Checa 2007: 3). As reconstituições mais antigas realizadas 
a partir dos restos estruturais preservados, anteriores ao isolamento da área e da escavação do teatro no século XX, foram preparadas por arquitetos renascentistas. Tais reconstituições foram feitas por: G. Battista Da Sangallo, junto com seu irmão Antonio B. Da Sangallo (FIGURA 5A); G. B. Da Sangallo, que realizou sua própria reconstituição (FIGURA 5B); e S. Serlio, que trabalhou a partir de uma planta de Baldassarre Peruzzi (FIGURA 5C) (Checa 2007: 54).

Considerando que até os anos 1930 e 1940 não foram realizados estudos arqueológicos no teatro, ocupado por depósitos de iodo e por unidades de habitações muito simples em volta do edifício, a planta realizada pelos irmãos Da Sangallo possui muitas imprecisões. $\mathrm{Na}$ arcada interna foi representada uma escada no eixo do teatro que não existiu na realidade, havendo também uma incorreta posição das duas basílicas laterais, excluindo a presença da frons scaenae. A planta de G. B. Da Sangallo, apesar de possuir interpretações mais úteis, como maior precisão nas escadas das arcadas internas da cavea, também apresenta problemas de interpretações estruturais (Checa 2007: 55-56)9 . Já a planta de S. Serlio, representada a partir de B. Peruzzi, apesar de possuir mais detalhes, foi fiel aos vestígios do teatro representados pela família Da Sangallo.

Posteriores a estas, na Era Moderna, outras plantas foram compiladas, tais como: as de A. Desgodetzs (FIGURA 5D), G.B. Piranesi (FIGURA 5E), L. Canina (FIGURA 5F), L. Vandoyer (FIGURA 5G), R. Lanciani (FIGURA 5H) e P. Ruga (FIGURA 5I). Das plantas Theatrum Marcelli feitas no século XX destacam-se em primeiro lugar a planta de Kiepter e Hülsen (FIGURA 5L), que é praticamente uma cópia de L. Canina; a planta de Jordan e Hülsen (FIGURA 5J); e a planta de E. Fischer (FIGURA 5K) (Checa 2007: 56-57)

9 Para uma profunda interpretação e análise dos problemas estruturais de cada planta do Teatro de Marcelo, ver Checa (2007: 57-59).

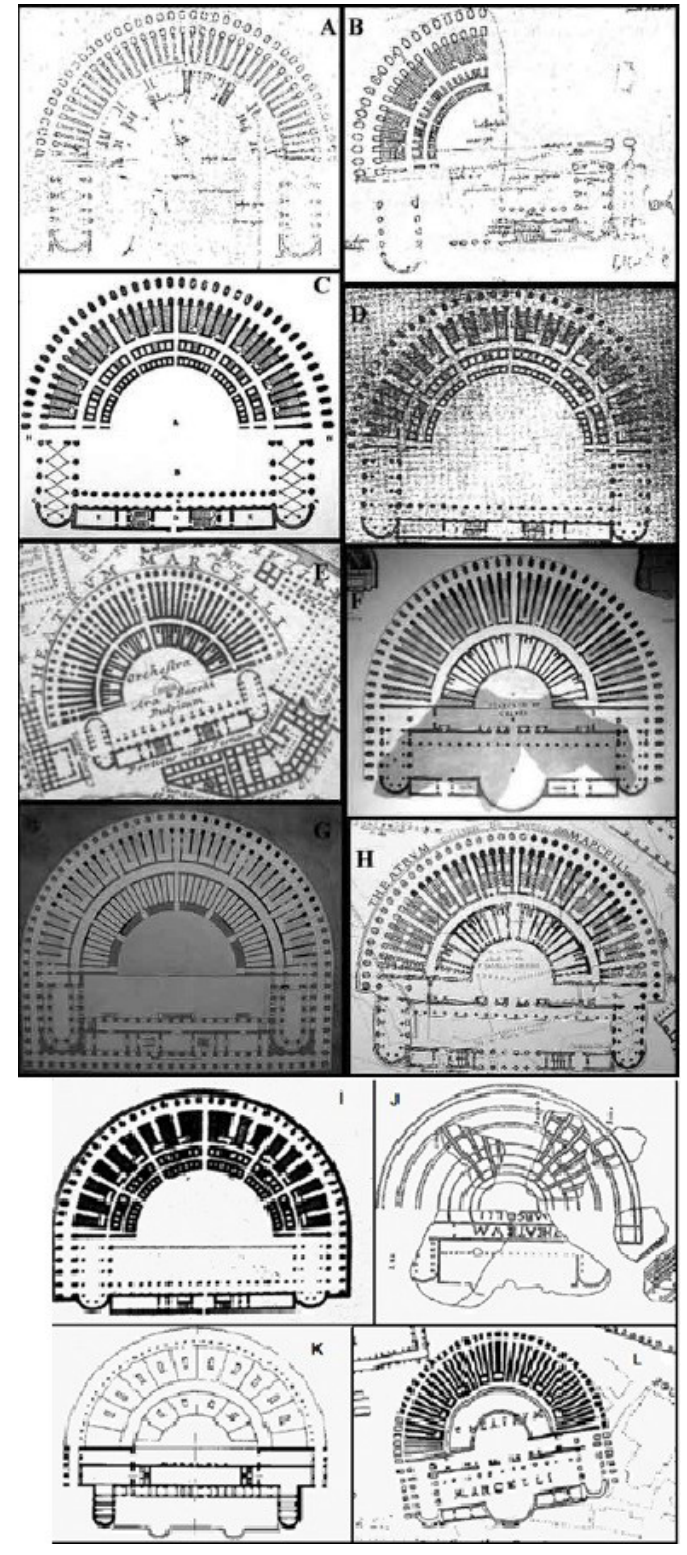

Fig. 5. Plantas do Teatro de Marcelo.

Fonte: Checa (2007: 57-59).

O teatro foi restaurado e consolidado sob a direção de Alberto Calza-Bini (1953) e seu assistente Paolo Fidenzoni (1970) (FIGURA 6 e FIGURA 7, respectivamente). Foram esses os trabalhos que resultaram nos primeiros planos precisos acerca da cavea, embora os arranjos do palco e da construção da scaenae ainda sejam 
desconhecidos. O motivo de destacarmos os estudos desses autores se deve ao fato de que eles produziram análises mais concretas sobre as escavações do Teatro de Marcelo. Isto é, esses estudiosos elaboraram estudos centrados nos assentos destinados ao público, levando em consideração as escavações arqueológicas do espaço. Entretanto, segundo Frank Sear em sua obra Roman theatres: an architectural study (2006), há certas divergências estruturais entre as plantas de Calza-Bini e Fidenzoni relacionadas à divisão de assentos da ima cavea e da existência de um pórtico na parte superior do teatro.

Calza-Bini dividiu a ima cavea em duas zonas, uma de onze e outra de sete filas de assentos. Fidenzoni reconstruiu uma ima cavea mais ortodoxa, com quatorze filas de assentos e incluiu um locus senatorius. Calza-Bini dividiu o ima cavea em seis cunei principais com dois menores nos lados. Fidenzoni apresentou seis escadas de superfície em consonância com o vomitorium ${ }^{10}$, dividindo o ima cavea em cinco principais cunei com dois menores nas laterais (Sear 2006: 64).

Entre outras diferenças, Calza-Bini mostra uma visão diferente da reconstrução da summa cavea, argumentando que não há evidências de um pórtico. Ou seja, ele não se convenceu de que a descoberta de dois capitéis (parte superior da coluna ornamentada) de ordem coríntia pudesse ser prova de uma fachada inteira. Apesar disso, ambos trazem valiosas informações acerca das características físicas do teatro, como o desenho da planta baixa e de sua possível reconstrução interna.

Uma percepção que temos dessa bibliografia é a dificuldade de edificação de uma planta única do Teatro de Marcelo devido às inúmeras mudanças estruturais no monumento. Apesar de existirem maiores informações sobre a estrutura

10 Corredores abobadados que levam para dentro ou fora do teatro. $\mathrm{O}$ vomitorium era ligado à lateral das criptas sob a cávea formando uma rede eficiente de entradas e saídas para o público (Hines 2003). interna e a seção das arquibancadas, os arranjos de palco cênico e da construção da scaenae ainda possuem questões arqueológicas abertas. Partindo de uma mesma topografia e de um trabalho comum feito durante a recuperação do monumento, os próprios estudos arquitetônicos de Fidenzoni e de Calza-Bini possuem certas interpretações diferentes.

Assim, uma vez que observamos as mudanças sofridas pelas plantas baixas do teatro ao longo da bibliografia que se dedicou a analisálas, entendemos a necessidade de comparar tais transformações arquitetônicas da planta do teatro ao Forma Urbis Romae (FIGURA 8). Os historiadores que possuem trabalhos mais atuais acerca do Teatro de Marcelo, Antonio M. Checa (2005), Marialetizia Buonfiglio $(2010,2015)$ e Paola C. Rossetto (2010), destacam a importância da interpretação da planta baixa do teatro através da utilização do Forma Urbis Romae, ou Plano de Mármore Severano. Nas palavras de Buonfiglio e Rossetto "A substancial sobreposição dos setores individuais da estrutura é semelhante com o que é representado no Plano de Mármore, podendo este fornecer as medidas e as proporções do edifício atualmente enterradas" (2010: 53-54).

Esse mapa, esculpido no terceiro século d.C. e edificado por Septímio Severo, mostra em detalhes o Teatro de Marcelo ${ }^{11}$ e outros monumentos da cidade de Roma, medindo ao todo um pouco mais de dezoito metros de largura e treze de altura. A escala, porém, não é consistente, sendo sugeridas várias estimativas médias. Atualmente restam apenas dez a quinze por cento do gigantesco mapa, sobrevivendo apenas 1.186 peças (Taub 1993). A visualização em conjunto, as plantas baixas edificadas a partir das escavações arqueológicas em conjunto com a Forma Urbis Romae, fornecem dados mais precisos sobre a constituição interna do Teatro de Marcelo (FIGURA 9).

11 Para a visualização dos fragmentos do Plano de Mármore Severano, ver placas do Teatro de Marcelo: 2962 (Stanford Digital Forma Urbis Romae Project). 

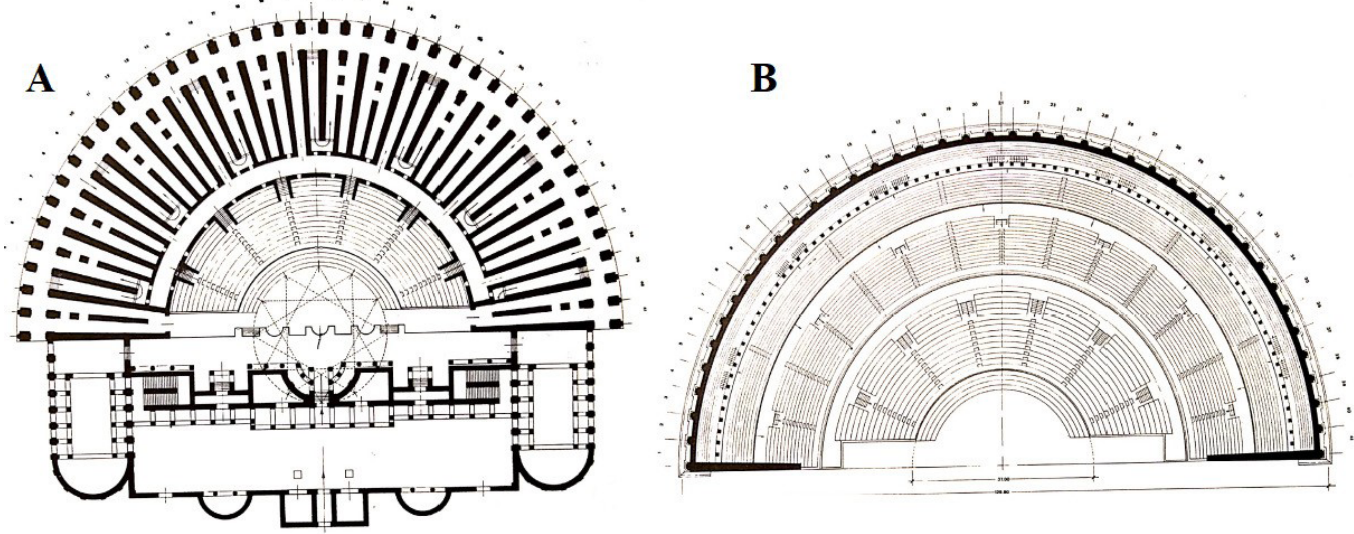

Fig. 6. Teatro de Marcelo. A - Planta da configuração interna do teatro. B - Reconstituição da cavea em nível superior. Fonte: Fidenzoni (1970: 41, 49).

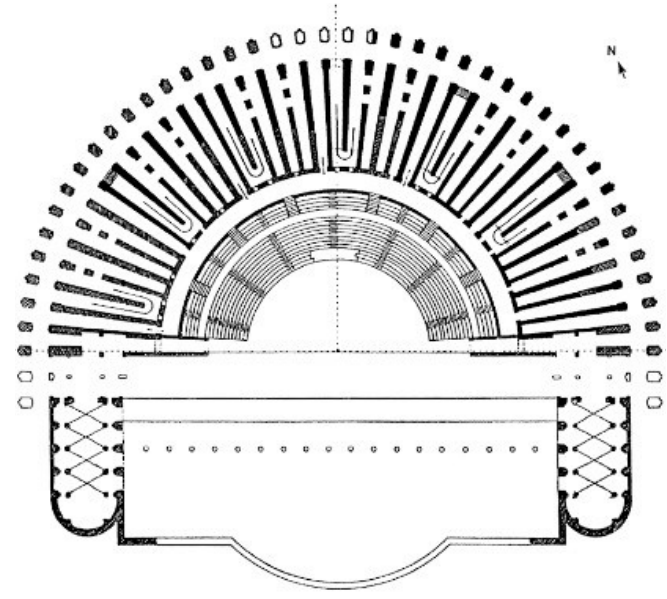

Fig. 7. Teatro de Marcelo.

Fonte: Sear (2006: 135)

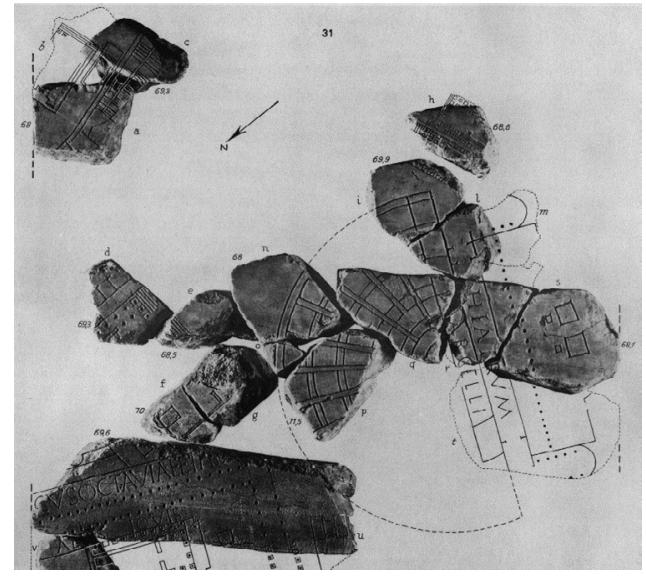

Fig. 8. Fragmentos conservados da Forma Urbs do Teatro de Marcelo. Placas: 2962 il.

Fonte: Stanford Digital Forma Urbis Romae Project. 


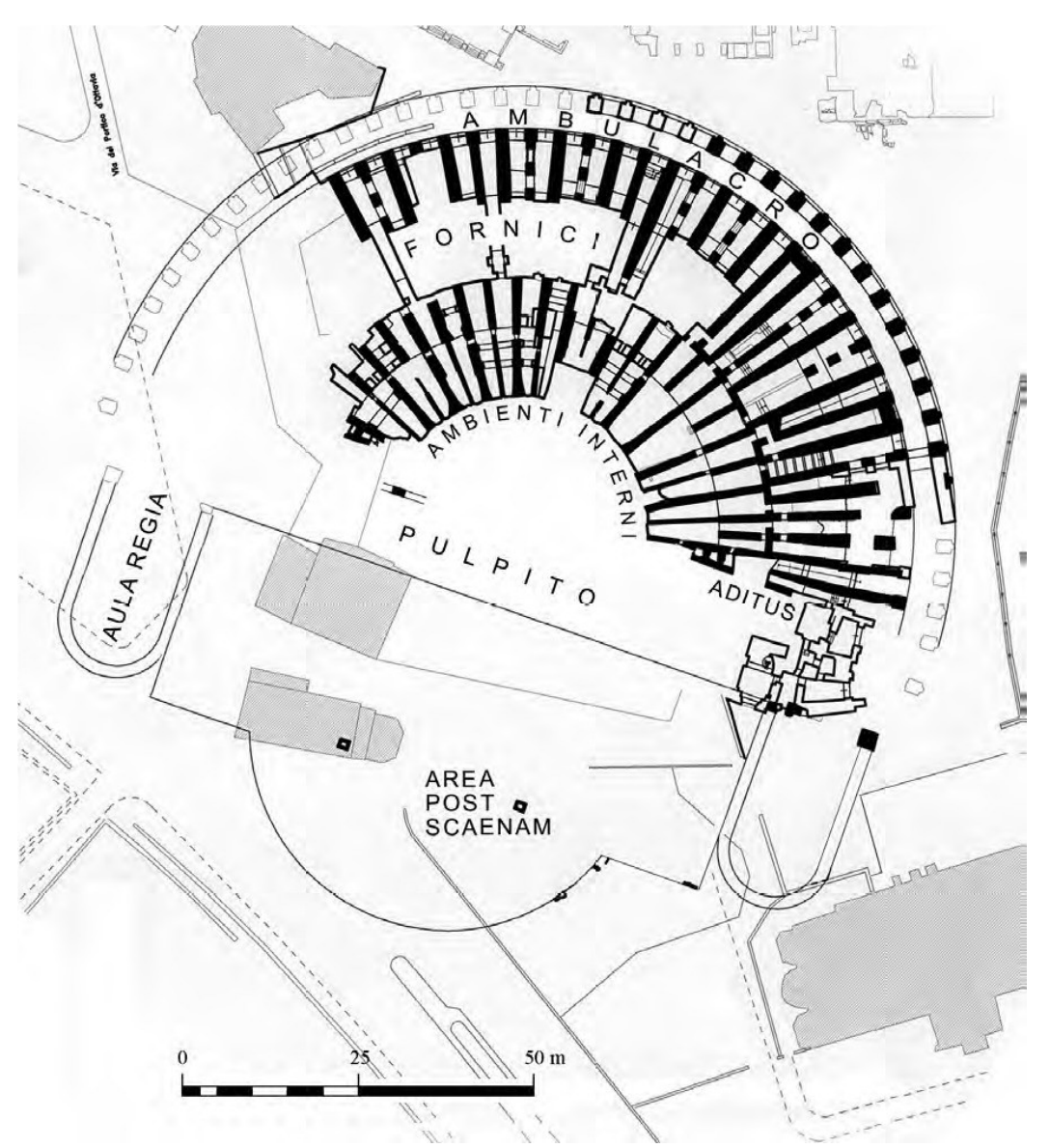

Fig. 9. Teatro de Marcelo: planta baixa efetuada por Paola C. Rossetto após escavações e em comparação com o Plano de Mármore Severano.

Fonte: Rossetto \& Buonfiglio (2010: 53).

\section{Estrutura interna do Teatro de Marcelo}

Tendo como foco a construção do Teatro de Marcelo, destacamos que a maior parte dos estudos e obras sobre a arquitetura romana aborda o Teatro de Marcelo de uma maneira superficial, repetindo informações das primeiras obras realizadas por Calza-Bini e Paolo Fidenzoni. Alguns poucos estudos, porém, evidenciam a estrutura do Teatro de Marcelo e sua construção, como o artigo de Antonio M. Checa intitulado "Sobre los orígenes helenísticos del modelo teatral romano: los primeiros teatros en plano de Italia" (2005). Nesse texto, o autor discute as mudanças arquitetônicas dos teatros romanos, já que estes possuíram fortes influências helenísticas, e evidencia como o Teatro de Marcelo consolidou um novo modelo de teatro romano. Segundo Checa, mesmo que o teatro de Pompeu seja o primeiro edifício deste tipo que foi fixo em Roma, ele não foi o primeiro teatro "romano" da Itália no que tange ao modelo construtivo.

O teatro dedicado por Augusto ao seu herdeiro frustrado é, ao mesmo tempo, o fim de uma evolução construtiva, desenvolvido no helenismo, e o começo da difusão de um modelo arquitetônico, que somente se inicia quando o teatro de Marcelo está totalmente definido. O modelo romano, com a construção do teatro de Marcelo, 
toma uma nova direção. As novas leis dos anos 20 a.C., e especialmente a Lex Iulia Theatralis, conferem para o teatro uma fragmentação arquitetônica até agora desconhecida (Checa 2005: 97).

\section{O autor afirma que o Teatro de Marcelo} inaugura uma nova arquitetura, e entre as novidades estão uma articulação global das comunicações internas, ou seja, aspectos arquitetônicos que contribuíram para uma melhor movimentação das pessoas dentro do edifício, e maiores fragmentações sociais nos assentos da cavea, com a estipulação de três arquibancadas na cavea. Outros teatros posteriores procuraram seguir essas novas configurações (Checa 2005: 97). O próprio Teatro de Pompeu, remodelado por Augusto, apresentou a reserva de assentos por toda a cavea após suas renovações. Houve também a construção inédita de um ambulacro interno ${ }^{12}$, que se conectou com as primeiras 14 fileiras da arquibancada sob a ima cavea, projetado para receber os membros da ordem equestre e colocálos em posição mais isolada em relação aos demais participantes (Checa 2005: 98).

Anteriormente às escavações realizadas por Calza-Bini e Fidenzoni, a preservação e a imponente fachada arquitetônica do edifício já despertavam atenções. Segundo o artigo "Planos de arquitectos españoles publicados en Roma (s. XIX): el Teatro de Marcelo y el Santuario de Hércules Vencedor" (2008), de Jorge G. Sánchez, no século XVIII, estudiosos romanos e espanhóis, interessados em contemplar as artes greco-romanas como uma solução estética, tiveram seus olhares atraídos pelos monumentos da antiguidade romana.

Segundo o autor, essas obras representam uma documentação importante sobre o estado dos monumentos clássicos da época e "refletem as preocupações arqueológicas do Iluminismo" (Sánchez 2008: 178). Já que

12 Em termos arquitetônicos o ambulacro significa local para andar. $\mathrm{O}$ ambulacro também pode designar o conjunto de arcadas inferiores e superiores do Teatro de Marcelo, o ambulacro dórico, e segundo andar, o ambulacro jônico. um dos monumentos estudado é o Teatro de Marcelo, o artigo contribui ao apresentar restituições anteriores às de Calza-Bini e Fidenzoni, ajudando-nos a compreender com mais profundidade as partes constituintes do teatro, em especial sua estrutura interna.

Sánchez coloca ainda que esses arquitetos, em sua maior parte espanhóis, tinham como objetivo examinar esses monumentos através de uma análise detalhada, ou seja, procuravam medir e desenhar com precisão, apontar a decoração conservada e projetar sua reconstrução ideal. $\mathrm{O}$ autor destaca, ademais, o uso de fontes clássicas para essas restituições, a saber: documentos da biblioteca romana e a numismática; enfatizando, assim, a utilização de um método mais científico na abordagem do conhecimento da arquitetura greco-romana nesse período.

Os arquitetos e autores dos desenhos foram Isidro González Velázquez (1765-1840), Silvestre Pérez (1767-1825) e Evaristo del Castillo (1769-1798), sendo recompilados por Giovanni Battista Cipriani na obra Monumenti di fabbriche antiche estratti dai disegni dei piu celebri autori, de 1803. Esses arquitetos espanhóis estavam presentes em Roma entre os períodos de $1791 \mathrm{e}$ 1796 graças a uma pensão dada pelo rei Carlos IV e pela Real Academia de Belas Artes de San Fernando (Sánchez 2008: 178-179).

$\mathrm{O}$ arquiteto Silvestre Pérez se aproximou do teatro ainda inserido na confusa imagem urbana romana, ou seja, antes que a área fosse isolada e tivessem sido iniciadas as escavações pelo governo italiano no século XX. Pérez delineou doze planos do Teatro de Marcelo por volta do ano de 1794, levantando planos da planta, fachadas principais e laterais. Outros arquitetos, como Castillo e Velázquez, também procuraram medir e delinear o teatro, seus desenhos foram gravados em oito lâminas por G. B. Cipriani no volume três de sua obra Monumenti di fabbriche antiche, de 1803 (Sánchez 2008: 196). Duas destas lâminas demonstram a estrutura interna (ambulacro interno e subterrâneo) do Teatro de Marcelo (FIGURA 10A e FIGRUA 10B). Esses desenhos preocupavam-se também com as cornijas (moldura de entablamento da coluna), os capitéis e as bases das colunas, além de desenhos do pórtico perdido. 


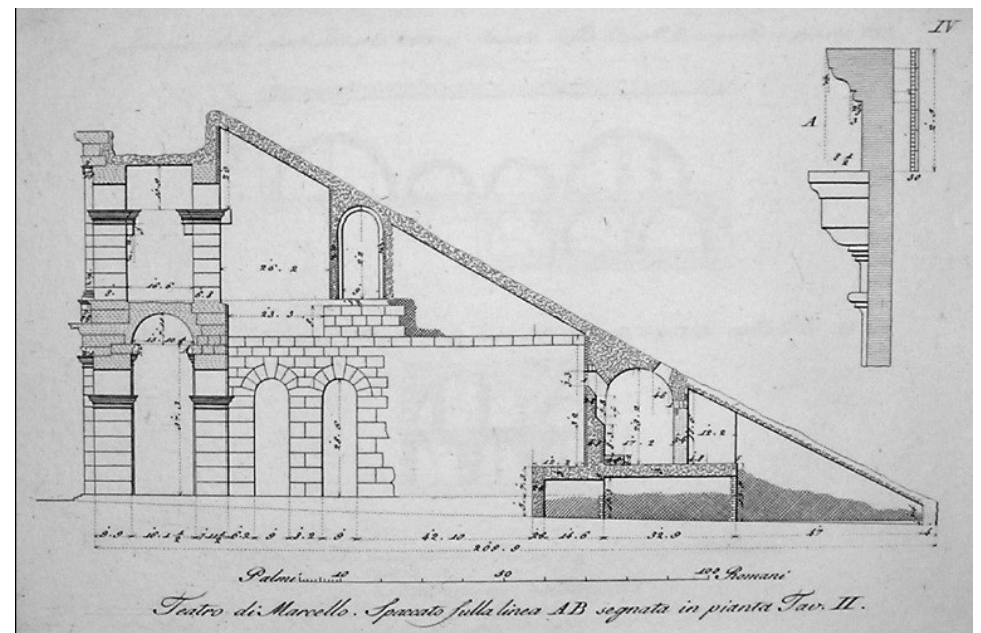

Fig. 10A. Configuração interna do Teatro de Marcelo, segundo Castillo e Velázquez (lâmina IV). Fonte: Sánchez (2008: 194-195).

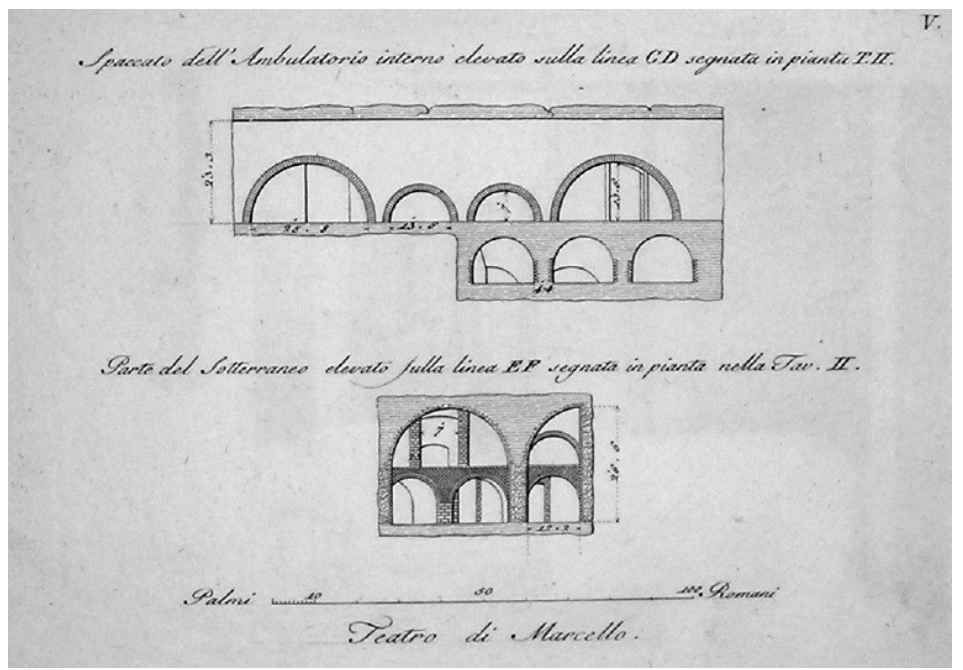

Fig. 10B. Ambulacro interno e subterrâneo do Teatro de Marcelo, segundo Castillo e Velázquez (lâmina V). Fonte: Sánchez (2008: 194-195).

Apesar de a estrutura do teatro permanecer em pé até hoje, é imprescindível que busquemos entender melhor sua constituição no período em que foi construído. Para isso, deve-se atentar aos aspectos arqueológicos, que trazem à luz os processos inerentes à passagem do tempo. Um dos estudos mais atuais acerca do teatro é o artigo "Teatro di Marcello: analisi e riflessione sugli aspetti progettuali e costtrutivi" de Paola C. Rossetto e Marialetizia Buonfiglio. Nesse estudo, as autoras procuram trazer à tona as novas investigações sobre o processo construtivo do Teatro de Marcelo, principalmente através da análise material e das escavações mais atuais do edifício, destacando as inovações arquitetônicas que esse modelo teatral impôs ao período.

O Teatro de Marcelo é sem dúvida o melhor exemplo de teatro romano já preservado, um edifício com uma sólida unidade arquitetônica, com a 
scaenae conectada com a cavea, terminando com uma fachada semicircular. A cavea é suportada por um sistema muito avançado, do ponto de vista da engenharia, e particularmente elaborado em relação a circulação dos espectadores, que se deslocam por um sistema de cuneis radiais e ambulacros externos e internos de altitudes variáveis (Rossetto \& Buonfiglio 2010: 53).

$\mathrm{O}$ artigo levanta muitas informações relacionadas aos ambientes que possibilitavam a transição dos espectadores dentro do teatro e aponta outros dados. Aborda questões relacionadas à estrutura do teatro, discutindo também sua fundação e as mudanças arqueológicas desde sua construção original, além de olhar com mais atenção para o que restou do palco e da scaenae do teatro.

Desde a fundação do teatro, foram reveladas as técnicas arquitetônicas utilizadas e as problemáticas arqueológicas da estrutura atual. A localização do edifício, próximo ao rio Tibre, demonstra as características complexas da área: uma planície aluvial, sujeita a inundações. O próprio trabalho para a fundação foi complexo e exigente, sendo necessário cavar uma profundidade considerável. Segundo os estudos de Fidenzoni (1970), para a parte da orchestra e cavea foram cavados cerca de 7,5 metros abaixo da superfície. No geral, uma escavação de quase $51 \mathrm{mil} \mathrm{m}^{3}$.

A camada geológica em que se encontra o teatro é pouco sólida, composta por argilas, limos e areia por até 30 metros de profundidade.
Assim, para sustentar a construção, foi necessário a utilização de uma paliçada de carvalho, com postes colocados entre 10 e $20 \mathrm{~cm}$ de distância um do outro. Esse processo ocorreu na parte externa da cavea em correspondência ao ambulacro externo, ou seja, onde foram distribuídas cargas mais altas (FIGURA 11). Após a colocação de postes, foi lançado o cimento - constituído por um aglutinante de cal, argamassa e cinzas pozolânicas por todo espaço da cavea e da orchestra (Rossetto $\&$ Buonfiglio 2010: 56).

Esse sistema arquitetônico é conhecido na antiguidade, sendo demonstrado pelo arquiteto romano Vitrúvio em seu tratado De Architectura ${ }^{13}$, escrito entre 35 a.C. e 25 a.C. A obra, composta por dez livros, expõe importantes concepções sobre o espaço romano e os monumentos que compõem a cidade e suas formas de construção ideal. Para além disso, a obra de Vitrúvio se destaca por trazer à tona inúmeros assuntos do período em que foi escrito, tais como as orientações para a gênese das cidades romanas, a demonstração de um arcabouço de autores e pensadores célebres, costumes e práticas, tanto no âmbito social como no âmbito arquitetônico, técnicas da maquinaria, descrição de lugares históricos, saberes relacionados à música, astronomia, filosofia e medicina, entre outros.

13 A dissertação de mestrado em desenvolvimento pela autora, intitulada O Imperador Augusto e a construção do Teatro de Marcelo: o espaço físico e o espaço político para a Consagração de um Princeps (séc. I a.C. - I d.C.), utiliza-se dos escritos de Vitrúvio para analisar a concepção do espaço teatral romano.

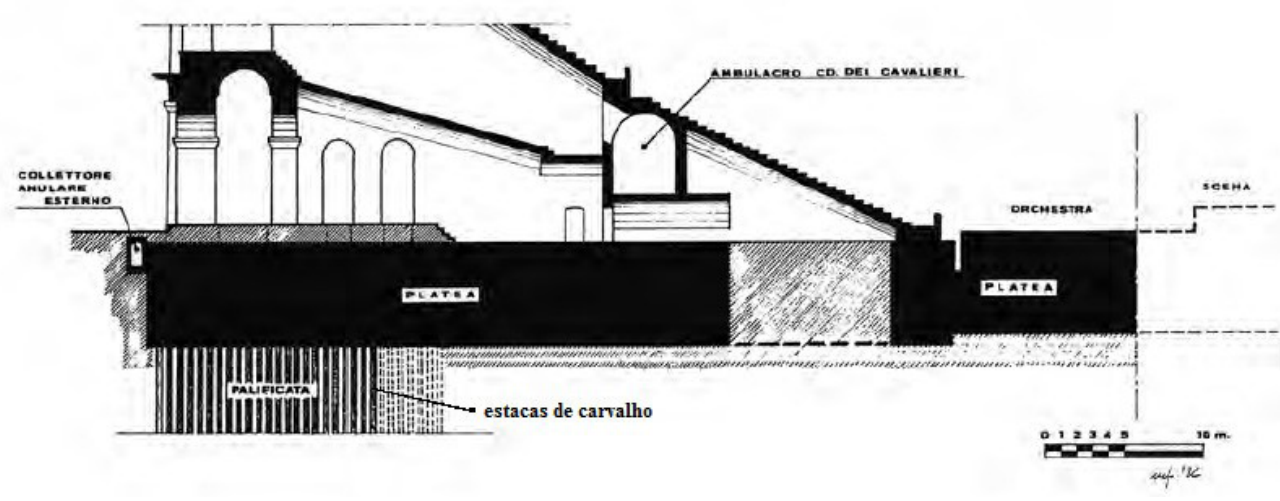

Fig. 11. Teatro de Marcelo: seção da fundação.

Fonte: Rossetto \& Buonfiglio (2010: 56). 
O processo descrito por Vitrúvio aparece no livro III, capítulo 4.2, ao tratar especificamente sobre a consolidação das fundações. Vitrúvio recomenda a utilização dos mesmos tipos de materiais como carvalho, carvão e concreto para áreas pouco sólidas,

Se, todavia, não se encontrar chão firme e o lugar de aluvião profundo ou paludoso, então escava-se e drena-se esse local, consolida-se cravando-se com estacas de salgueiro e oliveira ou carvalho endurecias ao fogo, bate-se com máquinas a estacaria envolvente o mais junta possivel, preenchem-se totalmente de carvão os interstícios e, finalmente enchem-se os fundamentos com concreto o mais consistente possivel (Vitrúvio 2007: 4, 2).

A respeito da parte interna, a cavea repousa sobre estruturas que no piso térreo são divididas em três zonas: iniciando com o ambulacro, uma série de arcos alongados, e, finalmente, uma faixa de corredores com ambientes internos, atualmente mal iluminados e difíceis de acessar. Os arcos foram construídos com um sistema modular organizado em ritmo de seis, com funções e características estruturais diferenciadas. Alguns ambientes do piso térreo foram provavelmente utilizados como lojas e armazéns, outros constituíam as entradas reais para o teatro.

O ambulacro dórico, o mais alto, era constituído por 43 pilastras com a meia-coluna externa e pilastra interna, que delimitava ao todo 39 arcos e duas entradas (porodoi) (FIGURA 12) (Rossetto \& Buonfiglio 2010: 56). Os ambulacros externos e internos, localizados em vários níveis, constituíam as principais junções de locomoção para os espectadores, usando-se também do vomitorium, corredores que levavam para a entrada ou saída do teatro.

$\mathrm{O}$ acesso para a ima cavea era feito por sete rampas que subiam levemente para uma galeria interna, denominada ambulacro de Cavalieri $^{14}$ (FIGURA 13). Outras sete rampas,

14 Considerou-se apropriado, para uma melhor compreensão, manter as denominações dos setores e edifícios informados por técnicos e estudiosos no momento da intervenção de restauração no Teatro de Marcelo (1926-1932) e usado em publicações mais tarde (Rossetto \& Buonfiglio 2010: 57). que ficavam em dois arcos adjacentes com um pouso intermediário, levavam ao andar superior jônico e, a partir daí, havia junções adicionais, na summa cavea. As várias galerias presentes, ainda visíveis, podem ser usadas para localizar com mais precisão a cavea. As galerias internas - Ambulacro de Cavalieri e o pequeno ambulacro superior (FIGURA 14) - provavelmente sustentam em seus estrados os recintos e as passagens dos percursos internos que possuem diferentes mudanças de inclinação entre os níveis (FIGURA 15) (Rossetto \& Buonfiglio 2010: 60).

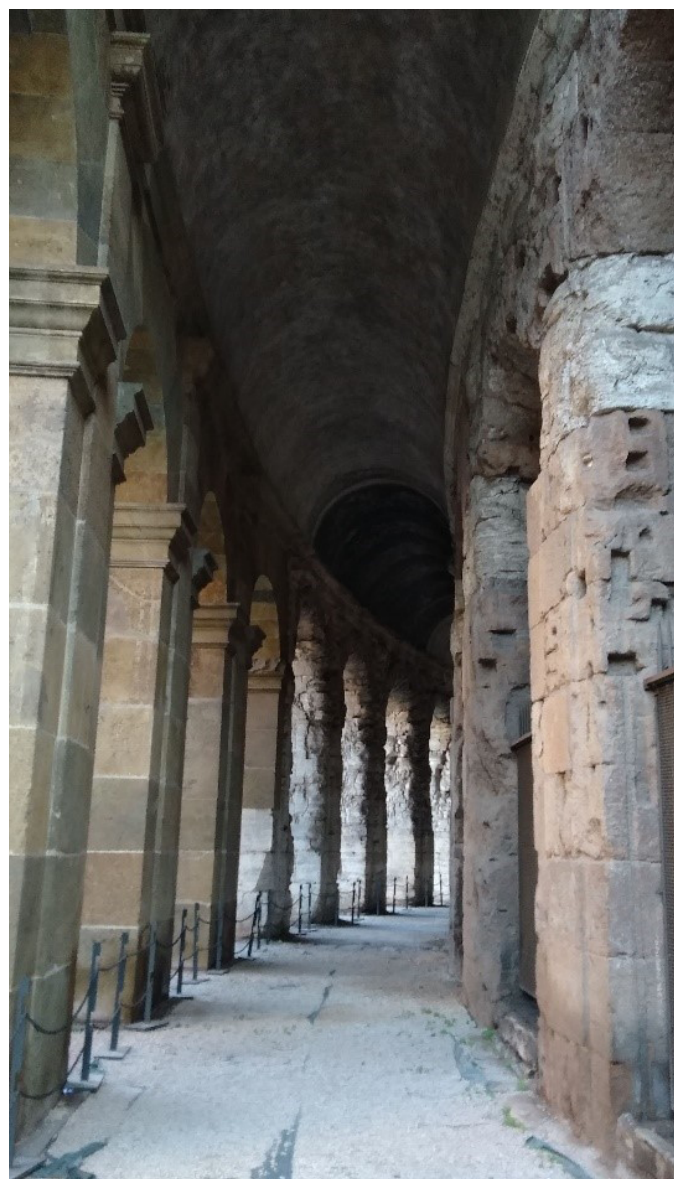

Fig. 12. Ambulacro dórico do Teatro de Marcelo: entradas do teatro.

Fonte: Fotografia de Letícia A. P. Passos (2020). 


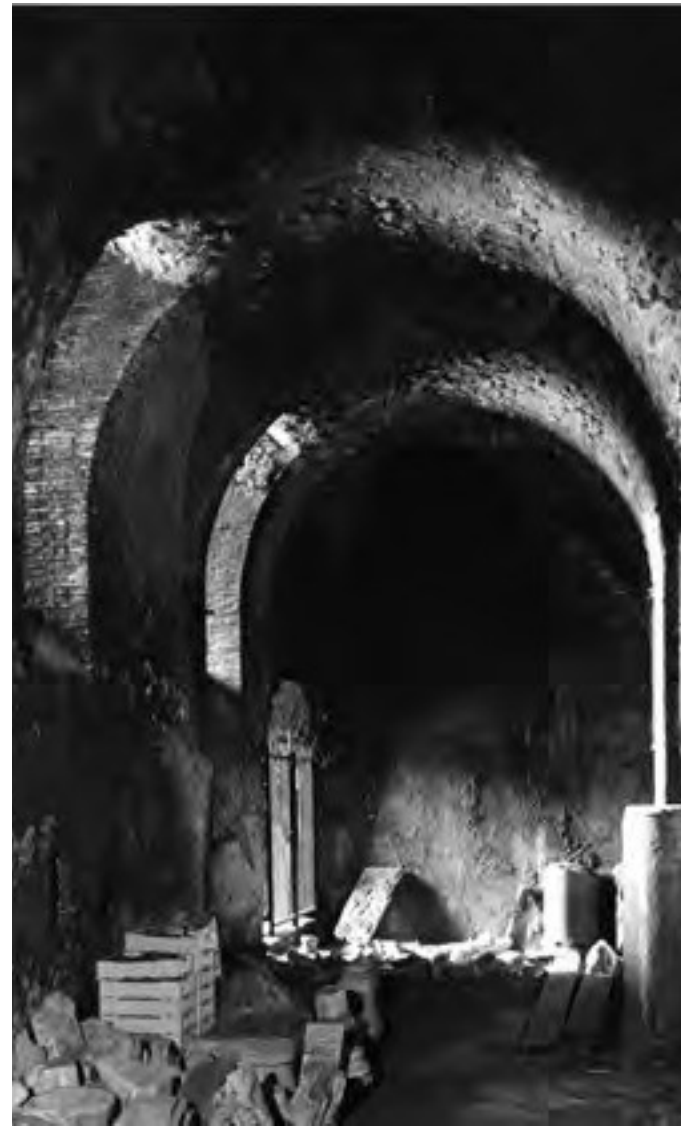

Fig. 13. Ambulacro de Cavalieri.

Fonte: Rossetto \& Buonfiglio (2010: 60).
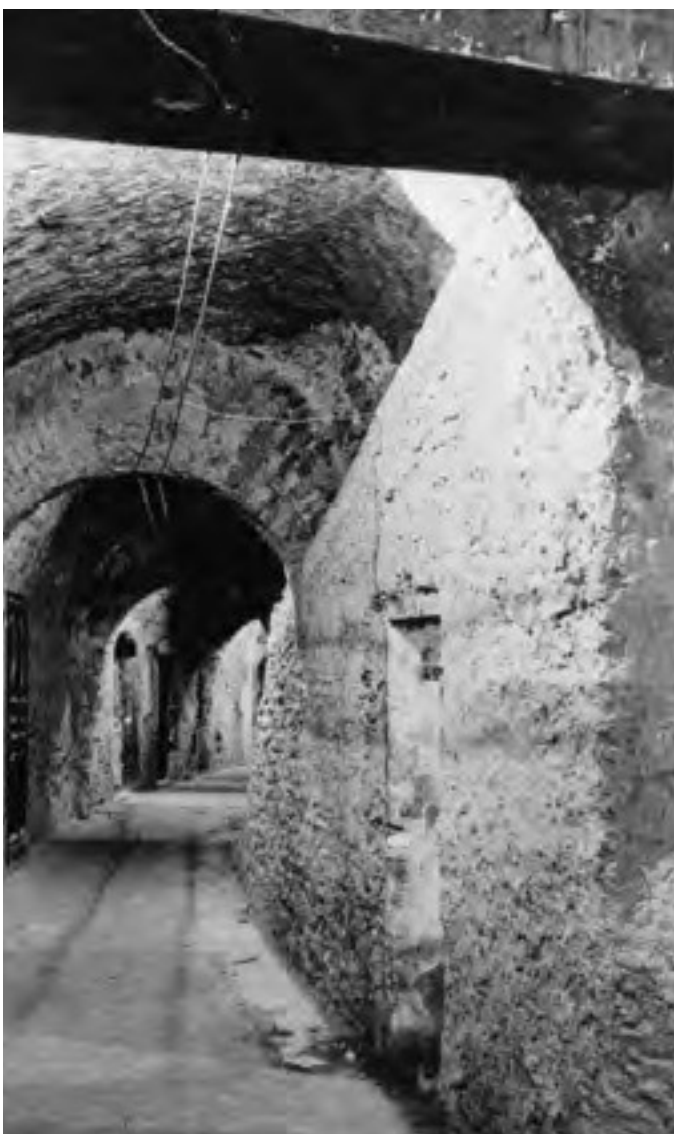

Fig. 14. Pequeno ambulacro superior.

Fonte: Rossetto \& Buonfiglio (2010: 61).

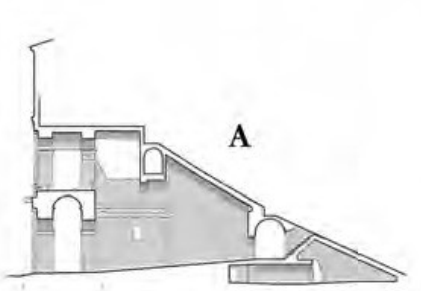

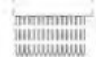
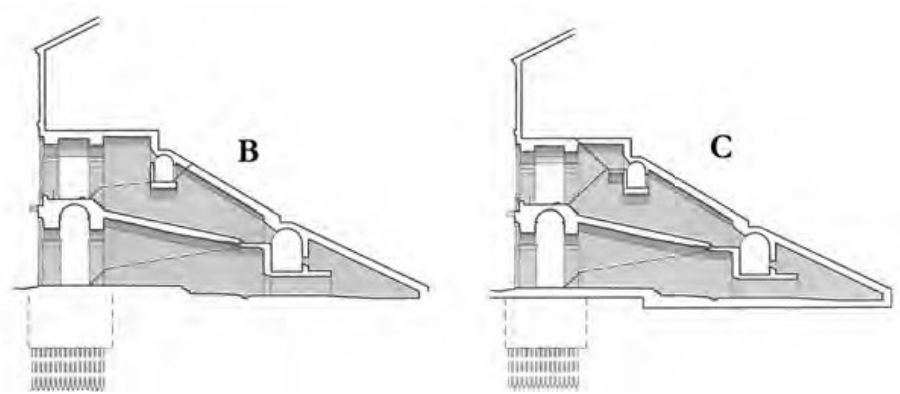

Fig. 15. Teatro de Marcelo: seção reconstrutiva da passagem interna. A - ima cavea; B - media cavea; C - summa cavea. Fonte: Rossetto \& Buonfiglio (2010: 63). 
Segundo Rossetto \& Buonfiglio, para construir um edifício tão complexo foi necessário o uso de técnicas e materiais de várias tipologias. Primeiramente, as peças de sustentação foram construídas: uma gaiola vertical que define $\mathrm{o}$ ambulacro dórico, sendo as paredes radiais em opus reticulatum ${ }^{15}$, e o Ambulacro de Cavalieri. Essas estruturas formavam os suportes a partir dos quais se conectavam as seções das paredes radiais, constituindo, ao mesmo tempo, o sistema de contenção e de rolamentos. A mesma sequência foi adotada para a construção dos andares superiores.

O Teatro de Marcelo pode, com razão, representar a presença de diferentes técnicas de construção, quase um protótipo do clima experimental que caracteriza a República tardia e a Idade Augusta, com paredes estruturais feitas de travertino e tufo quadrado e em trabalhos de cimento com revestimentos em opus reticulatum e em opus latericium (tijolos). A face da parede das galerias semianulares internas (o chamado ambulacro de Cavalieri e o chamado "pequeno ambulacro superior") representa o primeiro exemplo do uso de tijolos em um edifício monumental, permitindo abordar os novos parâmetros da abordagem da cronologia tradicional do opus testaceum ${ }^{16}$ (tijolos cozidos) queimados) em Roma (Buonfiglio 2010: 109).

Peter Rose destaca a presença do espectador dentro de três monumentos específicos e de tipologias diferentes: o Teatro de Marcelo, o Coliseu e o Circo Máximo. Em seu artigo "Spectators and spectator comfort in Roman

15 Comum na época imperial, consiste na construção em alvenaria com tijolos de tufa e barro, com a face exterior em forma de losango, formando um padrão diagonal, revestindo um interior mais espesso de opus caementicium (concreto romano) (Albuquerque 2017).

16 A terminologia usada neste artigo refere-se essencialmente às indicações de G. Lugli, que derivou as normas descritivas baseadas na interpretação de fontes antigas em seu trabalho de 1957. Os termos mais usados são structura latericia ou opus latericium, para identificar paredes feitas de tijolos crus, e opus testaceum para cobrir as paredes com tijolos queimados (Lugli 1957: 529). O termo opus identifica a alvenaria secundária que oculta o trabalho de cimento na fachada (Lugli 1957: 363). Geralmente, no uso atual, o termo "opera laterizia" identifica os adornos feitos com tijolos e fragmentos de ladrilhos (Buonfiglio 2015: 13-14). entertainment buildings: a study in functional design" (2005). Rose analisa os aspectos arquitetônicos que garantiam a entrada, saída e circulação de muitas pessoas. Também chama a atenção como a hierarquia presente no teatro refletia-se nas configurações de assentos, nas condições visuais e acústicas e na circulação dentro dos edifícios de entretenimento,

Roma era em grande parte uma sociedade altamente política e socialmente dividida, cada cidadão pertencia a um grupo separado ou a uma ordo. Isto pode ser visto especialmente durante o governo de Augusto, quando a ênfase foi colocada sobre esta divisão na forma de legislação, que penetrou todos os niveis e aspectos da sociedade romana Isto foi melhor refletido no teatro romano por um extenso conjunto de regulamentos, Lex Julia Theatralis, detalhando a disposição de seu público em seções (Rose 2005: 100).

\section{Sobre a circulação, Rose destaca aspectos} nos edifícios de entretenimento romanos que se aproximaram das determinações arquitetônicas atuais, seguindo duas regras básicas: conforto e segurança. Ou seja, os espectadores deveriam ser capazes de se mover com conforto e de encontrar seu caminho com segurança, sem se perderem ou serem empurrados. Para além disso, os espectadores deveriam ser capazes de se mover da entrada para seus assentos de forma rápida de modo que o edifício fosse preenchido em um tempo razoável e que os espectadores pudessem fazer o mesmo caminho na direção inversa (Rose 2005: 103).

Apesar da utilização de técnicas vistas no Teatro de Pompeu, o sistema eficiente de circulação está fortemente presente no Teatro de Marcelo, uma vez que a estrutura verdadeiramente inovadora deste teatro foi o ambiente acima do Ambulacro de Cavalieri, gerado por critérios de racionalização da gestão e distribuição dos acessos. O fluxo de espectadores foi transmitido por galerias semianulares, não apenas externas, mas internamente, em vários níveis. A solução adotada no Teatro de Marcelo forneceu um novo modelo arquitetônico, suscetível a outras articulações durante o primeiro século d.C., 
porém mais adequado e funcional às necessidades dos edifícios de entretenimento (Rossetto \& Buonfiglio 2010: 63).

Um amplo pavimento de travertino originalmente cercava a fachada semicircular do Teatro de Marcelo, permitindo, assim, o fácil acesso a cada uma das 41 baias de entrada ao nível do solo. Dali, uma série de passagens radiais conduzia diretamente a um ambulacro abaixo da ima cavea ou a longas rampas subindo pelo edifício. Entre eles havia uma série de três salas que poderiam ter sido usadas, por exemplo, como lojas ou latrinas. Dependendo do seu status social, os espectadores seguiriam para um ambulacro inferior, onde havia acesso para a ima cavea (primeiro setor de fileiras da arquibancada) através dos vomitoria, ou subiam por rampas para o ambulacro superior, onde lances de escadas levavam para a media e summa cavea. Para os senadores havia duas entradas separadas, em ambos os lados do palco, levando diretamente à orchestra (Rose 2015: 112).

Rose também fornece um diagrama de fluxo (FIGURA 16) do Teatro de Marcelo, mostrando, de forma esquemática, um padrão de circulação ideal, em que as opções foram reduzidas às decisões: sim ou não. Utilizando um diagrama de fluxo para prédios de entretenimento atuais e da combinação dos desenhos axonométricos e planos fornecidos por G. Bomgardner em seu trabalho sobre os anfiteatros romanos (1988: 368 apud Rose 2005), Rose elabora um diagrama para cada um dos três monumentos estudados, para o Teatro de Marcelo,

Cada coluna vertical representa uma das entradas arqueadas dos edificios, enquanto as linhas horizontais representam uma das passagens anulares. As setas indicam um vomitorium e um círculo indica onde o espectador tem uma escolha entre entrar na cavea ou prosseguir. Assim, eu estendi o método de Golvin para ilustrar a eficiência do edifício em fornecer fluxo suave e seguro de espectadores. [...] Um sistema de circulação altamente eficiente é revelado, onde cada espectador é guiado para seu assento por simples escolha em cada interseção. Podemos ver como a primeira decisão do espectador na entrada afeta todas as suas escolhas posteriores, segregando-o do resto do prédio. Ele é forçado a permanecer dentro do mesmo grupo se quiser alcançar seu assento de uma maneira mais rápida e simples (Rose 2005: 110-111).

No Teatro de Marcelo visualiza-se um sistema em que a ênfase está no fluxo de baixo para cima através do edifício. Embora tenha menor capacidade que um circo ou um anfiteatro, leva-se em conta o baixo gradiente de sua cavea usando rampas. Há muitas vantagens para o uso de rampas em vez de escadas, uma vez que são mais seguras para andar, e permitem um fluxo muito maior e mais rápido de pessoas. As escadas ainda são o método mais compacto de circulação vertical, e, mesmo com a desvantagem de serem menos seguras, são uma maneira muito rápida de descer um prédio. Por isso, muitas das vezes visualizam-se rampas ou declives suaves usados apenas nas partes mais baixas e mais espaçosas dos edifícios, enquanto as escadas dominam completamente os níveis mais altos de todos os tipos de edifícios de entretenimento (Rose 2005: 112).

O ambulacro tem também um papel importante a desempenhar como dobradiça estrutural entre os arcos e os ambientes internos. Essa solução, segundo Rossetto \& Buonfiglio, foi implementada experimentalmente, e será elaborada em edifícios de entretenimento posteriores (2010: 59). O Ambulacro de Cavalieri aparece notavelmente iluminado quando comparado com estruturas similares: o vasto corredor é iluminado, obtendo luz diretamente da cavea por meio dos vomitoria, e, a partir do exterior, pelas rampas de acesso e pelas grandes janelas. Assim, percebe-se a inovação do Teatro de Marcelo que será copiado em partes por outros teatros romanos (ou itálicos).

O Teatro de Marcelo, por ser o teatro mais 'perfeito', foi por muito tempo uma exceção, que não será funcionalmente combinado até a construção do teatro de Benevento. Os teatros augustanos na Itália levarão tempo para assimilar globalmente as consequências de tão alta evolução arquitetônica (Checa 2005: 101-103). 


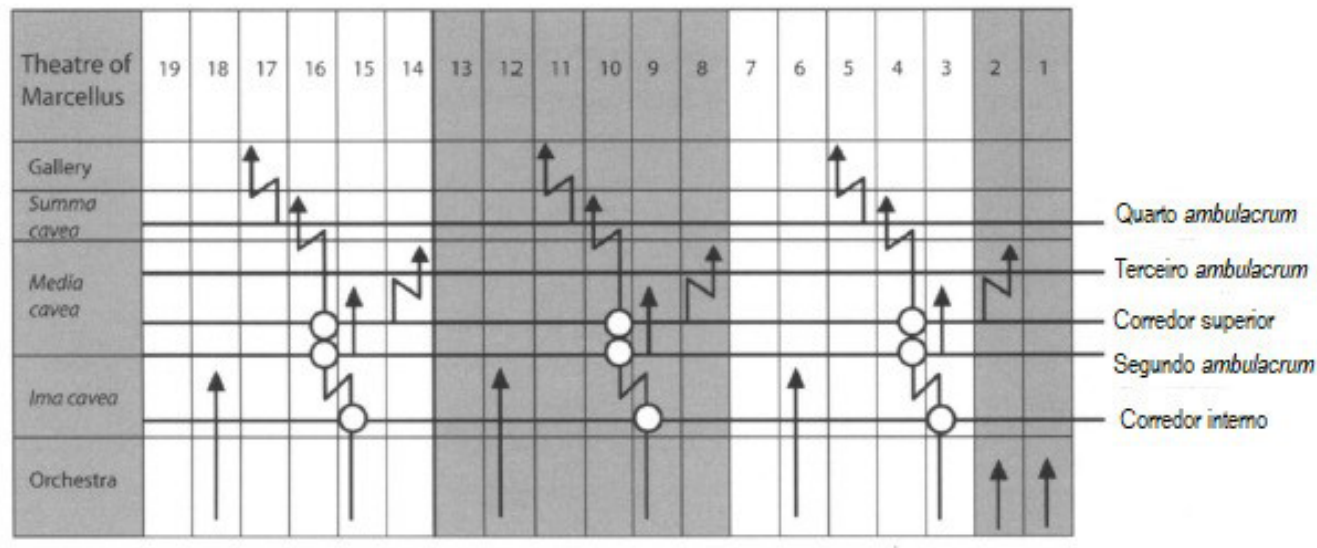

Fig. 16. Gráfico da análise do sistema de circulação do Teatro de Marcelo.

Fonte: Rose (2005: 111).

Os teatros eram estruturas religiosas, mas também prédios seculares construídos precisamente para exibir uma série de espetáculos públicos que rapidamente se expandiram de tragédia e comédia para incluir espetáculos teatrais, festivais musicais e atléticos, exibição de animais selvagens, entre outros (Gutiérrez 2004: 9-10). Com um óbvio significado político, a presença e relacionamento do imperador com a sociedade romana em um evento marcado trazia à tona as aspirações e aclamações de clientes, atores, atrizes e até mesmo espectadores.

\section{Conclusões}

Os estudos relacionados ao Teatro de Marcelo, seus aspectos gerais, suas plantas e suas informações arqueológicas recentes levantaram inúmeros pontos acerca de sua estrutura arquitetônica. Percebemos a inovação construtiva tanto no âmbito da circulação do teatro, possibilitado pela construção do inédito ambulacro interno, quanto pela utilização de diferentes técnicas e materiais mais resistentes. Aqui destaca-se o papel da arqueologia, que ligada ao urbanismo, fornece a reconstituição da planimetrias das cidades e monumentos, tipologias, alçados e volumetrias que, no limite, podem propor formas de usos dos espaços e sugerir padrões de comportamento pautados pela organização e distribuições dos edifícios e espaços urbanos (Martins 2018; Wallace-Hadrill 1988).

Sabemos que os romanos costumavam atribuir um papel de primeira grandeza ao espaço urbano como força motriz das relações sociais. Dessa forma, assim como outros elementos citadinos, como as praças, os fóruns, as casas de banho, o espaço do teatro romano reflete inúmeros elementos simbólicos: interesses, aspirações, categorias sociais, encontro e troca de informações etc. Ou seja, elementos que carregam um potencial afetivo e cognitivo,

Apreendido na sua dimensão geográfica-cultural, o espaço pode ser considerado sob um duplo viés: o de produto e o de produtor do social, desempenhando a partir dai uma multiplicidade de funções; a de um amplo quadro no interior do qual os grupos sociais se organizam do ponto de vista da fixidez e da mobilidade e estabelecem regras de convivio e de socialização; a de um suporte de obras materiais, muitas das vezes eternizadas em pedra; a de um ambiente no qual práticas e representações encontram seu ponto de convergência (Neto 2018: 9).

Assim, nosso ponto de convergência permanece nesta significação espacial do Teatro de Marcelo, o nexo indissolúvel entre o ambiente e seus usuários (pois a disposição de qualquer lugar constitui uma componente decisiva nas atividades que ali deveriam ocorrer), utilizado como um instrumento pelo Imperador Augusto. 
Através de estudo do espaço físico do Teatro de Marcelo, visualizamos uma intensa preocupação do novo Princeps por construir um teatro romano com um alto grau de inovações e que estivesse associado a seu nome, sendo este copiado em parte por teatros posteriores, instalando-se como um modelo arquitetônico a ser seguido.
Dessa forma, trabalhamos com uma perspectiva ainda não vista na historiografia nacional ou estrangeira (britânica e ibérica) ao utilizarmos diferentes tratos documentais - ou seja, fontes escritas e visuais - entrelaçando a análise do espaço físico do Teatro de Marcelo e a importância política de sua construção.

PASSOS, L.A.P. The Theatre of Marcellus: historiography and perception of the theatrical space (1st c. BC). R. Museu Arq. Etn., 36: 191-211, 2021.

\begin{abstract}
During the transition from the Republic to the Principate, along with arts, literature and architecture, Romes's urban image was used by Emperor Augustus as an instrument to legitimize the power of his new government and his own image. As Julius Caesar's heir, the Princeps aimed to modernize the city by building great public monuments. Among these buildings is the Theatre of Marcellus, one of the largest theatres of the Roman Empire. First used in $17 \mathrm{BC}$ for the Secular Games and formally devoted to the Emperor's nephew and heir, the theatre could welcome over 15,000 people. Despite the obvious changes inherent to the passage of time and the restorations performed, the monument structure of the theatre remains. Therefore, deepening in the studies of theatrical physical space, we will pursuit to expose the construction of the Theatre of Marcellus, presenting its internal structure and its architectural innovations. For being this a monument somehow unattended by current historiography, we seek to deliver a broad discussion about the present studies on the Theatre of Marcellus, which provides us with the complexity of its floor plans and archaeological discoveries. Finally, we will present two three-dimensional reproductions found, reasoning the 3D space with the historiographic information.
\end{abstract}

Keywords: Principate; Augustus; Theatre of Marcellus; Theatrical space; Three-dimensional reconstitution.

\title{
Referências bibliográficas
}

Albuquerque, M. 2017. Tecnologias de construção romanas. Disponível em: $<$ https://bit. ly/3jkSAE4>. Acesso em: 02/09/2019.

Athenaeus. 1854. The Deipnosophists. Translated by C. D. Young. Disponível em: $<$ https://bit. ly/3qyZQA6>. Acesso em: 11/02/2020.

Augustus Caesar. 1967. Res Gestae Divi Augusti: The achievements of The Divine Augustus. Oxford
University Press, Oxford. Disponível em: $<$ https://bit.ly/3bzNraU $>$. Acesso em: 20/06/2020.

Berthold, M. 2001. A história mundial do teatro. Perspectiva, São Paulo,

Brothers, A.J. 1989. Buildings for entertainment. In: Barton, I.M. (Ed.). Roman public buildings. University of Exeter, Exeter. 
Buonfiglio, M. 2010. M. E. Blake e lo sviluppo dellopus testaceum a Roma: il' caso del Teatro di Marcello. Musila e Sectilla 7: 109-122.

Buonfiglio, M. 2015. Lutilizzo di laterizi nella costruzione augustea del Teatro di Marcello. In: Anais do Workshop Laterizio, Archeologia dell' architecttura, il laterizio nei cantiere imperiali Roma e il Mediterraneo, 2014, Roma.

Calza-Bini, A. 1953. Il teatro di Marcello: forma e strutture. Centro di Studi per la Storia dell'Architettura, Roma.

Checa, A.M. 2005. Sobre los orígenes helenísticos del modelo teatral romano: los primeros teatros en plano de Italia. Revue archéologique 47: 3-51.

Checa, A.M. 2007. La frons scaenae del Theatrum Marcelli según la forma Urbis Marmorea, primeros planteamientos de un problema abierto. Romula 6: 1-74.

Claridge, A. 2010. Roman an Oxford archeological guide. Oxford University Press, New York, 275-276.

Dio Cassius. 1924. Roman History. Harvard University Press, Cambridge, volume 7, books 56-60.

Fidenzoni, P. 1970. Il Teatro di Marcello. Liber, Roma.

Gonçalves, A.T. 2002. As festas imperiais na Roma antiga: os decennalia e os jogos seculares de Septímio Severo. Mneme 3: 16-34.

Grimal, P. 1978. Teatro antigo. Edições 70, Lisboa.

Grimal, P. 2009. As cidades romanas. Edições 70, Lisboa.

Gutiérrez, O.R. 2004. O teatro romano de Itálica: estudio arqueoarquitectónico. Servicio de Publicaciones de la Universidad Autónoma de Madrid, Madrid.

Hines, T.G. 2003. The ancient theatre archive: greekroman theatre glossary. Whitman College, Walla Walla. Disponível em: <https://bit.ly/3m2RM8G $>$. Acesso em: 24/09/2019.
Kubity. Theatre of Marcellus with tour. 2017. Disponível em: $<$ https://bit.ly/3rMBwfa $>$. Acesso em: 10/07/2020.

Lugli G. 1957. La tecnica edilizia romana con particolare riguardo a Roma e Lazio. Roma, Bardi Edizioni.

Martins, M. 2008. Espaços, usos e sociabilidade na cidade antiga: contributos e limites da Arqueologia. In: Silva, G.V.; Silva, É.C.M.; Neto, B.M.L. (Orgs.). Usos do espaço no Mundo Antigo. GM., Vitória, 8-11.

Neto, B.M.L. 2018. A arena pública de Cartago como espaço de recuperação da honor de Apuleio de Madaura. In: Silva, G.V.; Silva, É.C.M.; Neto, B.M.L. (Orgs.). Usos do espaço no Mundo Antigo. GM., Vitória, 106-129.

Polybius. 2012. The Histories. Harvard University Press, Cambridge, volume 6, books 28-39, fragments.

Progetto Traiano. 2014. Teatro di Marcello. Disponível em: <https://bit.ly/3kl0rmn $>$. Acesso em: 02/07/2019.

Richardson, L. 1992. A new topographical dictionary. Johns Hopkins University Press, Baltimore; London, 384-385.

Rose, P. 2005. Spectators and spectator comfort in roman entertainment buildings: a study in functional design. Papers of the British School at Rome 73: 99-130.

Rossetto, P.C.; Buonfiglio, M. 2010. Teatro di Marcello: analise e riflessione sugli aspetti progettuali e costtrutive. In: Anais do 2. Arqueología de la Construcción, Los Procesos Constructivos em el Mundo Romano: Italia e Provincias Orientales, 2010, Siena.

Sánchez, J.G. 2008. Planos de arquitectos españoles publicado en Roma (s. XIX): el Teatro de Marcelo y el Santuario de Hércules Vencedor. Archivo Español de Arqueología 81: 177-200. 
Sear, F.B. 2006. Roman theatres: an architectural study. Oxford University Press, Oxford.

Silva, G.V. 2015. Ordem e desordem na cidade antiga: o teatro entre a tradição clássica e cristã. In: Vieira, A.L.B.; Rosa, C.B. (Orgs.). Teatro grego e romano, história, cultura e sociedade. Editora Uema, São Luís, 251-280.

Stanford Digital Forma Urbis Romae Project. Disponível em: <https://stanford.io/2HqgUHk>. Acesso em: 31/01/2019.

Suetonius. 1914. The Lives of the Caesars: Julius. Augustus. Tiberius. Gaius. Caligula. Harvard University Press, Cambridge.
Taub, L. 1993. The historical fuction of the Forma Urbis Romae. Journal Imago Mundi 45: 9-19.

Valentini, R.; Zucchetti, G. 1940. Codice Topografico della città di Roma. Istituto Storico Italiano per il Medio Evo, Rome, volume 1.

Vitrúvio. 2007. Tratado de arquitetura. São Paulo, Martins.

Vitruvius. 1960. The ten books on architecture. New York, Dover Publications.

Wallace-Hadrill, A. 1988. The social structure of the roman house. Papers of the British School at Rome 56: 43-97. Disponível em: <https://bit. ly/2ITwNHh>. Acesso em: 22/07/2020. 